\title{
Analysis of tumour marker CA 15-3 in breast cancer following surgery
}

\author{
Mohd Aizaz $\operatorname{Khan}^{1}{ }^{*}$, Harsh P. Trivedi ${ }^{1}$, Alaknanda N. Atara ${ }^{2}$ \\ ${ }^{1}$ Department of Surgery, Shri M.P. Shah Medical College, Jamnagar, Gujarat, India \\ ${ }^{2}$ Department of Pathology, Shri M.P. Shah Medical College, Jamnagar, Gujarat, India
}

Received: 07 May 2016

Accepted: 10 June 2016

\section{*Correspondence:}

Dr. Khan Mohd Aizaz,

E-mail: k.m.aizaz@gmail.com

Copyright: ( $\odot$ the author(s), publisher and licensee Medip Academy. This is an open-access article distributed under the terms of the Creative Commons Attribution Non-Commercial License, which permits unrestricted non-commercial use, distribution, and reproduction in any medium, provided the original work is properly cited.

\section{ABSTRACT}

Background: CA 15-3 is a mucin belonging to a large family of glycoprotein's encoded by the MUC1 gene. Elevated pre-operative CA 15-3 level is directly related to tumour burden and independent prognostic factors for breast cancer. It could be considered for clinical use such as predicting patient outcome and determining adjuvant treatment for better outcome.

Methods: In this study 30 female patients diagnosed with carcinoma breast were staged according to TNM classification and Serum CA 15-3 level were assayed by ELISA method before surgery and one month after surgery.

Results: In present study on comparing preoperative serum CA 15-3 level to the postoperative level, it was found that CA15-3 level falls following breast surgery. Patients with Stage I showed fall in CA 15-3 level and came to normal level i.e from $37.8 \pm 6.9 \mathrm{U} / \mathrm{mL}$ to $30.3 \pm 3.1 \mathrm{u} / \mathrm{ml}$. In Stage II there was also fall in CA 15-3 level in all patients but few patients Ca 15-3 level was still above normal i.e from $44.98 \pm 14.32 \mathrm{U} / \mathrm{mL}$ to $34.98 \pm 13.95 / \mathrm{ml}$. In Stage III patients few showed fall in CA 15-3 levels but none came below normal whereas few patients showed rise in CA 15-3 level postoperatively compared to its preoperative level $(\mathrm{p}<0.001)$.

Conclusions: Serial measurement of CA 15-3 are more important to detect recurrence or metastasis at any time after treatment but even single postoperative CA 15-3 value together with preoperative value is of great importance. If postoperative CA 15-3 level remains stable or increases, it indicates chances of recurrence.

Keywords: Breast cancer, CA 15-3, TNM, Preoperative, Postoperative

\section{INTRODUCTION}

Breast cancer is the most common diagnosed malignancy in women worldwide (22\%) and in India (18.5\%) it ranks second to cervical cancer. The burden of breast cancer is increasing in both developed and developing countries; the peak occurrence of breast cancer in developed countries is above the age of 50 whereas in India it is above the age of $40 .{ }^{1}$ Prognosis of Breast cancer depends on evaluation of various parameters like tumour histological grading, cell proliferation index, oestrogen receptor status and lymph node status is of growing interest. ${ }^{2}$ The diagnosis of breast cancer at an earlier stage allows a woman more choice in the selection of treatment option. While physical examination and mammography are useful screening procedures for the early detection of breast cancer, they are also labor intensive and require health professionals who are highly trained and experienced. Nowadays, immuno-histochemistry and serum tumour marker detection is widely used in evaluation in case of breast carcinoma. Tumor markers may be used in diagnosis (early detection and differential diagnosis), prognostic evaluation and follow up (therapeutic monitoring). ${ }^{3}$

A frequently used staging system is the TNM (tumor, nodes, and metastasis) system given by American Joint Committee on Cancer (AJCC) demonstrated that tumor size correlates with the presence of axillary lymph node metastases. ${ }^{4}$ 
CA 15-3 is a mucin belonging to a large family of glycoprotein's encoded by the MUC1 gene. Elevated preoperative CA 15-3 level is directly related to tumour burden and independent prognostic factors for breast cancer. It could be considered for clinical use such as predicting patient outcome and determining adjuvant treatment for better outcome. ${ }^{5}$ The 2007 ASCO guidelines state that the routine use of CA 15-3 for screening, diagnosis,staging, or surveillance of breast cancer is not recommended because available data are insufficient. For monitoring patients during active therapy, CA 15-3 can be used in conjunction with diagnostic imaging and history and physical examination CA 15-3 determination is particularly useful in evaluating recurrence of disease and response to treatment. ${ }^{6}$

\section{METHODS}

This retrospective study was done on patients in Department Of Surgery, at tertiary care hospital, affiliated to Medical College, from April 2012 to March 2014. Total 30 patients diagnosed with Carcinoma Breast were included in this study. Detailed history and clinical examination was done of all the patients. Routine and Specific investigation (ultrasonography, mammography and FNAC) was sent. Many patients in this study also underwent incisional or excisional biopsy before any treatment for confirmation. Sera samples of all these cases were collected on the day of surgery and sent for preoperative CA 15-3 estimation. Modified radical mastectomy (MRM) with axillary clearance was undertaken and specimen was sent for detailed histological diagnosis. Similarly again after 30 days of surgery patients samples were sent for postoperative CA 15-3 estimation.

In this study no controls were used, but based on other studies of CA 15-3which used controls, normal serum CA 15-3 level was taken as $35 \mathrm{U} / \mathrm{mL}$. Hence in this study also we have taken the normal CA 15 -level as $35 \mathrm{U} / \mathrm{mL}^{7-}$

${ }^{10}$ Blood samples were collected and processed generally within an hour. The samples were centrifuged and stored in multiple tubes at $-20^{\circ} \mathrm{C}$. The $\mathrm{CA} 15-3$ conjugates reagents prepared by the entire $1 \mathrm{ml}$ of conjugate concentrate to $21 \mathrm{ml}$ of the enzyme conjugate diluents. Washing buffer was prepared by adding $50 \mathrm{ml}$ of the buffer to $950 \mathrm{ml}$ of distilled water.

All the results of clinical examination, mammography, FNAC and CA 15-3 level before and after surgery were combined and then compared with histopathology examination. The study was approved by the Ethical Committee of the medical college and informed written and verbal consent was obtained from the cases. Serum CA 15-3 concentration was determined by CA 15-3 Enzyme Immunoassay Kit based on the principle of a solid phase enzyme-linked immunosorbent assay (ELISA), purchased from Diametra.
Statistical analysis was performed by SPSS 17 . One-way analysis of variance (ANOVA) test was used for the determination of relation between different breast cancer stages. Pre-operative and post-operative CA 15-3 values were compared using "paired t test". $\mathrm{P}<0.05$ was considered statistically significant.

\section{Inclusion Criteria}

- Patient presenting with clinical features of Carcinoma breast

- Female patient

- Age greater than 20 years.

\section{Exclusion Criteria}

- Age less than 20 years

- Healthy volunteers

- Male patients.

\section{RESULTS}

Table 1: Relation of Preoperative and Postoperative CA 15-3 level.

\begin{tabular}{|llll|}
\hline $\begin{array}{l}\text { Clinic } \\
\text { al } \\
\text { Stage }\end{array}$ & $\begin{array}{l}\text { Number } \\
\text { of cases }\end{array}$ & $\begin{array}{l}\text { CA 15-3 level } \\
\mathbf{u} / \mathbf{m l})\end{array}$ & $\begin{array}{ll}\text { Pre-op } \\
\text { Pean } \pm \text { S.D }\end{array}$ \\
\hline I & 3 & $37.8 \pm 6.9$ & $30.3 \pm 3.10$ \\
\hline II & 17 & $44.98 \pm 14.32$ & $34.98 \pm 13.95$ \\
\hline III & 10 & $99.41 \pm 18.24$ & $97.42 \pm 18.21$ \\
\hline
\end{tabular}

$\mathrm{P}$ Value $<0.01$

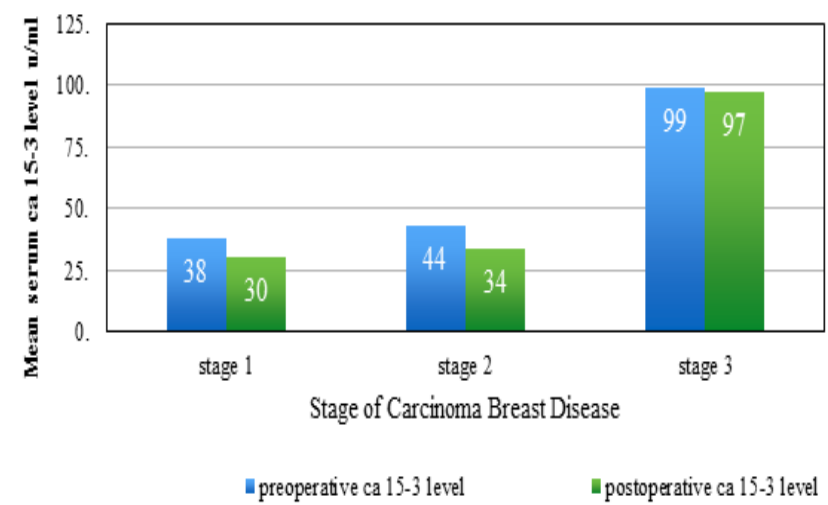

Figure 1: Relation of preoperative and postoperative CA 15-3 level according to stage of disease.

The mean serum CA 15-3 value for normal controls is below $35 \mathrm{U} / \mathrm{mL}$. In this study, $2 / 3$ patients with stage I disease showed preoperative CA 15-3 level $>35 \mathrm{U} / \mathrm{mL}$ whereas $14 / 17$ with stage II had CA $15-3$ level $>35 \mathrm{U} / \mathrm{mL}$. In stage III the preoperative level of CA 15-3 was raised in all $10 / 10$ patients. After one month of surgery, all patients with stage I disease showed decrease in CA 15-3 level compared to its preoperative level. 
In patients with stage II disease, 10/17 patients who had CA $15-3$ level $>35 \mathrm{U} / \mathrm{mL}$ showed reduction and its value came under normal level, whereas 4/17 patients CA 15-3 level also reduced but didn't come below $35 \mathrm{U} / \mathrm{mL}$. In stage III patients, 6 /10patients showed fall in CA 15-3 level compared to its preoperative level but none came below normal level of $<35 \mathrm{U} / \mathrm{mL}$ and on the other hand 4/10 patients with stage III had increased value of CA 153 than there preoperative level. In present study on comparing preoperative serum CA 15-3 level to the postoperative level, it was found that $\mathrm{Ca}$ 15-3 level falls following breast surgery i.e. from $61.71 \pm 29.43 \mathrm{U} / \mathrm{mL}$ mean preoperative level to $54.58 \pm 35.30 \mathrm{U} / \mathrm{mL}$ postoperative level.

Table 2: Statistical study.

\begin{tabular}{|c|c|c|c|c|c|}
\hline $\begin{array}{l}\text { CA 15- } \\
3 \text { Level }\end{array}$ & Mean & $\mathbf{N}$ & S D & SEM & $P$ value \\
\hline Pre op. & 61.71 & 30 & 29.43 & 5.37 & \multirow{2}{*}{$<0.001$} \\
\hline Post op & 54.58 & 30 & 35.30 & 6.44 & \\
\hline
\end{tabular}

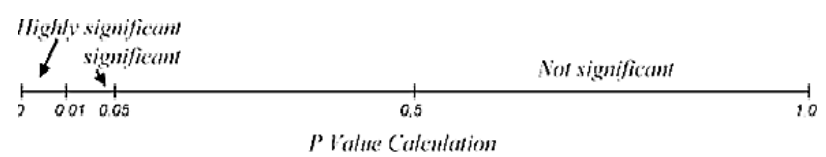

Here $\mathrm{P}$ value is highly significant. As $\mathrm{p}$ value $<0.001$.

\section{DISCUSSION}

In study conducted by Mahindocht et al in 2005 showed number of patients with the malignant breast lesion ( 6 out of 43) with elevated CA15-3 levels was higher than that in the normal controls ( 3 out of 39) and patients with benign lesions (1 out of 54). Forty percent of patients in stages II and III had a higher frequency of abnormal CA15-3 values, whereas $13 \%$ of those in stage I disease did so. One week after mastectomy, the mean \pm SD serum CA15-3 was $18.3 \pm 14.6 \mathrm{U} / \mathrm{mL}$. However, a month later, the mean $\pm \mathrm{SD}$ was $21.7 \pm 19.7 \mathrm{U} / \mathrm{mL}$, which was approximately the same as the preoperative values (mean $\pm \mathrm{SD}: 22.1 \pm 25.6 \mathrm{U} / \mathrm{mL}){ }^{7}$

In study conducted by Amina et al average plasma CA 15-3 concentration for breast cancer patients pretreatment has been $54.7 \mathrm{U} / \mathrm{mL}$ compare to $24 \mathrm{U} / \mathrm{mL}$ for breast cancer patients post-treatment. ${ }^{4}$ patients in this study showed an increase in their serum CA 15-3 concentrations more than its primary concentrations before starting therapy. ${ }^{8}$ Similar observations were made in studies conducted by Antonella et al found that the mean serum CA 15-3 levels in patients before surgery were significantly higher $(36.59 \mathrm{U} / \mathrm{ml})$ compared with those of CA $15-3$ after surgery $(27.11 \mathrm{U} / \mathrm{mL})$. We also found that elevated preoperative serum levels of CA 15-3 were significantly correlated with the presence of metastatic disease.

In particular, among $305 / 700$ patients $(43.6 \%)$ that displayed over cut-off ( $>40 \mathrm{U} / \mathrm{mL})$ preoperative levels of
CA 15-3, 94 patients $(30,8 \%)$ developed advanced disease (metastases to distant sites). By contrast, in a subgroup of $395 / 700$ patients $(56.4 \%)$ with CA 15.3 serum levels $<40 \mathrm{U} / \mathrm{mL}$, only $32 / 305$ patients $(8 \%)$ showed signs of advanced disease during follow-up. ${ }^{9}$

Hiba et al a statistically significant $(\mathrm{p}<0.05)$ increase was noticed in CA15-3 values across breast cancer stages; from stage I to stage III. The preoperative CA15-3 values were significantly higher than the values after three cycles of chemotherapy $(\mathrm{p}<0.05){ }^{10}$

Table 3: Comparison of the mean preoperative and postoperative CA 15-3 level of carcinoma breast patients.

\begin{tabular}{|lll|}
\hline Study & $\begin{array}{l}\text { Preoperative } \\
(\text { Mean } \pm \text { S.D } \\
\text { u/ml) }\end{array}$ & $\begin{array}{l}\text { Postoperative } \\
(\text { Mean } \pm \text { S.D } \\
\mathbf{u} / \mathbf{m l})\end{array}$ \\
\hline Mahindocht $^{7}$ & $22.10 \pm 25.6$ & $21.7 \pm 19.7$ \\
\hline Amina $^{8}$ & 54.7 & 24 \\
\hline Antonella $^{9}$ & 36.59 & 27.10 \\
\hline Hiba $^{10}$ & $87.03 \pm 23.54$ & $62.39 \pm 30.72$ \\
\hline Present study & $61.71 \pm 29.43$ & $54.58 \pm 35.30$ \\
\hline
\end{tabular}

In present study on comparing preoperative serum CA 15-3 level to the postoperative level, it was found that $\mathrm{Ca}$ 15-3 level falls following breast surgery i.e. from $61.71 \pm 29.43 \mathrm{U} / \mathrm{mL}$ mean preoperative level to $54.58 \pm 35.30 \mathrm{U} / \mathrm{mL}$ postoperative level.

Patients with Stage I showed fall in CA 15-3 level and came to normal level i.e from $37.8 \pm 6.9 \mathrm{U} / \mathrm{mL}$ to $30.3 \pm 3.1$ $\mathrm{U} / \mathrm{mL}$. In Stage II there was also fall in CA 15-3 level in all patients but few patients $\mathrm{Ca}$ 15-3 level was still above normal i.e from $44.98 \pm 14.32 \mathrm{U} / \mathrm{mL}$ to $34.98 \pm 13.95 / \mathrm{ml}$. In Stage III patients few showed fall in CA 15-3 levels but none came below normal whereas few patients showed rise in CA 15-3 level postoperatively compared to its preoperative level. $(\mathrm{p}<0.001)$. These findings suggest that CA 15-3 has definitive prognostic role ( $p$ value $<0.001$ ) in breast carcinoma. Even with normal preoperative CA 153 values, post-operative CA15-3 values are important to detect progression of disease, recurrence or metastasis.

\section{CONCLUSION}

Serial measurement of CA 15-3 are more important to detect recurrence or metastasis at any time after treatment but even single postoperative CA 15-3 value together with preoperative value is of great importance. If postoperative CA 15-3 level remains stable or increases, it indicates chances of recurrence.

Funding: No funding sources Conflict of interest: None declared

Ethical approval: The study was approved by the institutional ethics committee 


\section{REFERENCES}

1. Population based cancer registries consolidated report (1990-96). Available from: http://www.icmr.nic.in/ncrp/pbcr.pdf. Accessed on July 2016.

2. Taniguchi E, Yang Q, Tang W, Nakamura Y, Shan L, Nakamura $\mathrm{M}$, et al. Cytologic grading of invasive breast carcinoma. Correlation with clinicopathologic variables and predictive value of nodal metastasis. Acta Cytol. 2000;44(4):587-91.

3. Robles-Frias A, Gonzalez-Campora R, MartinezParra D, Robles-Frias M, Vazquez-Cerezuda T, Otal-Salaverri C, et al. Robinson cytologic grading of invasive ductal breast carcinoma. Correlation with histologic grading and regional lymph node metastasis. Acta Cytol. 2005;49(2):149-53.

4. American Joint Committee on Cancer: AJCC Cancer Staging Manual, 6th ed. New York: Springer, 2002: 227-228.

5. Yang E, Hu XF, Xing PX: Advances of MUC1 as a target for breast cancer immunotherapy. Histol Histopathol. 2007;22:905-22.
6. Harris L, Fritsche H, Mennel R, Norton L, Ravdin $\mathrm{P}$, Taube $\mathrm{S}$, et al. Journal of Clinical oncology. 2007;25(33):5287-312.

7. Keyhani M, Nasizadeh S, Dehghannejad A. Serum CA 15-3 measurement in breast cancer patients before and after mastectomy: Arch Iranian Med. 2005;8(4):263 -6.

8. Althwani AN, Najm MA. The Importance of CA153 in the Follow up of Meta- static Invasive Ductal Carcinoma Iraqi Women. Iraqi Journal of Cancer and Medical Genetics. 2011;4(1):7-10.

9. Antonella D, Rosa D, Paola T, Maria E, Angelo P, Antonio M. Clinical Usefulness of Cancer Antigen 15-3 in Breast Cancer Patients Before and After Surgery. The Open Breast Cancer Journal. 2013,5:1-6.

10. Ali HQ, Mahdi NK, Al-Jowher MH. The value of CA15-3 in diagnosis, prognosis and treatment response in women with breast cancer. Journal of Pakistan Medical Association. 2013;63(9):1138-41.

Cite this article as: Khan MA, Trivedi HP, Atara AN, Singh K. Analysis of tumour marker CA 15-3 in breast cancer following surgery. Int Surg J 2016;3:1491-4. 